\title{
ВПЛИВ МІЖНАРОДНИХ АСОЦІАЦІЙ НА РОЗВИТОК СОЦАЛЬНО-ПЕДАГОГІЧНОЇ РОБОТИ В УКРАЇНІ
}

\author{
Гладиш М. О. \\ кандидат педагогічних наук, \\ дочент кафедри сочіальної педагогіки та спеціальної освіти \\ Запорізький національний університет \\ вул. Жуковського, 66, Запоріжжя, Украӥна \\ orcid.org/0000-0002-7562-3953 \\ marigl@ukr.net
}

\author{
Ключові слова: \\ міжнародна асоиіація, \\ міжнародна федерація, \\ сочіальна педагогіка, \\ сочіально-педагогічна робота, \\ сочуіальна робота.
}

У статті розглянуто міжнародний та український розвиток соціальної роботи і соціальної освіти у XXI ст. Проаналізовано діяльність найбільш впливових міжнародних організацій у соціальній сфері та вплив діяльності міжнародних асоціацій на розвиток соціальної роботи та соціальної педагогіки в Україні.

Охарактеризовано діяльність міжнародних асоціацій, таких як: Міжнародна рада соціального забезпечення, Міжнародна асоціація шкіл соціальної роботи, Міжнародна федерація соціальних працівників, Європейська асоціація шкіл соціальної роботи.

Зазначено, що найбільш впливовою $є$ Міжнародна рада соціального забезпечення, структурні підрозділи якої займаютьсязборомі поширенням інформації, проведенням досліджень соціальних проблем та їх аналізом, підготовкою, проведенням семінарів і конференцій, вживають заходів щодо зміцнення неурядових організацій.

Виявлено, що значний вплив на навчання та підготовку фахівців 3 соціальної роботи в усьому світі здійснює Міжнародна асоціація шкіл соціальної роботи. Асоціація сприяє розвитку освіти в сфері соціальної роботи в усьому світі, розробляє стандарти для підвищення якості освіти в цій галузі, підтримує інтеграційні процеси, інтернаціональний обмін, здійснює спільні дослідження з питань соціальної роботи в освіті.

Однією із неурядових організацій, яка впливає на розвиток соціальнопедагогічної роботи в Україні, є Свропейська асоціація шкіл соціальної роботи. Асоціація об'єднує навчальні заклади (школи, університети, інші вищі навчальні заклади) та здійснюють підготовку фахівців соціальної роботи, сприяє розвитку соціально-педагогічної роботи по всій Європі, розробляє стандарти для підвищення якості соціальної роботи та здійснення освіти іiі фахівців, заохочує міжнародний обмін, забезпечує форуми для обміну дослідженнями в галузі освітньої діяльності.

Розкрито діяльність Міжнародної федерації соціальних працівників, яка здійснює підтримку фахівців соціальної сфери в питаннях створення необхідних умов праці, норм етики, участі у формуванні соціальної політики, освіти майбутніх соціальних працівників. Важливим завданням федерації $\epsilon$ удосконалення соціальної роботи як професії, підтримка національних асоціацій у питаннях соціального планування, розширення контактів, обміну досвідом соціальних працівників різних країн. 


\title{
THE INFLUENCE OF INTERNATIONAL ASSOCIATIONS ON THE DEVELOPMENT OF SOCIAL AND PEDAGOGICAL WORK IN UKRAINE
}

\author{
Hladysh M. O. \\ Candidate of Pedagogical Sciences, \\ Associate Professor at the Department of Social Pedagogy and Special Education \\ Zaporizhzhia National University \\ Zhukovsky str., 66, Zaporozhye, Ukraine \\ orcid.org/0000-0002-7562-3953 \\ marigl@ukr.net
}

Key words:

international association, international federation, social pedagogy, socio-pedagogical work, social work.
The article considers the international and Ukrainian development of social work and social education in the XXI century. The activity of the most influential international organizations in the social sphere and the influence of the activity of international associations on the development of social work and social pedagogy in Ukraine are analyzed.

It is noted that the most influential is the International Council on Social Welfare, which structural units are engaged in collecting and disseminating of information, conducting research on social problems and their analysis, preparation, seminars and conferences, take measures to enhance nongovernmental organizations.

It was found that the International Association of Schools of Social Work has a significant impact on the education and training of social workers around the world. The Association promotes the development of education in the field of social work around the world, develops standards to improve the quality of education in this area, supports integration processes, international exchange, conducts a cooperative research on social work in education.

It is highlighted the contribution of the European Association of Schools of Social Work. The Association unites educational institutions (schools, universities, other higher educational institutions) and provides training for social workers, promotes socio-pedagogical work throughout Europe, develops standards for improving the quality of social work and education of its specialists, contributes to the international exchange, provides forums for the exchange of research in the field of educational activities.

The activity of the International Federation of Social Workers is revealed, which provides support to social specialists in creating the necessary working conditions, ethics, participation in the formation of social policy, education of future social workers. An important task of the federation is to improve social work as a profession, support national associations in matters of social planning, increasing contacts, and the exchange of experience of social workers in different countries.
Постановка проблеми у загальному вигляді. Соціальна робота як різновид професійної діяльності утвердилася близько ста років тому в країнах Західної Свропи. За цей час у практиці соціальної роботи за кордоном сформувалася достатня кількість теорій, моделей, технологій цієї діяльності. У нашій країні соціальну роботу визнано як професію наприкінці XX ст. Запит сучасного суспільства щодо створення дієвої системи соціальної допомоги та соціального захисту населення призвів до розвитку соціальної роботи як професії та соціальної педагогіки як науки.
У цій статті простежено наукові роботи вчених, які займалися історією становлення соціальної роботи та соціальної педагогіки. Так, В. Буяшенко, В. Поліщук, М. Фірсов, П. Циткилов вказували на важливість під час формування професії соціального працівника знань про види, методи і форми соціальної допомоги окремим прошаркам населення в різні часи. Витоки соціальної роботи досліджували також А. Горілий, А. Капська, О. Карпенко, К. Кузьмін, І. Мельничук, М. Лукашевич, О. Янкович, Т. Семигіна, А. Фурман та інші, які здійснили історичний ана- 
ліз генезису відносин у практиці соціальної допомоги як основи професійної соціальної роботи. Етапи розвитку соціальної роботи та соціальної педагогіки досліджували О. Безпалько, І. Звєрєва, Г. Лактіонова, С. Харченко.

Метою статті $\epsilon$ визначення впливу міжнародних асоціацій, задіяних у соціально-педагогічній діяльності, на соціально-педагогічну роботу в Україні в минулому та в сучасних умовах.

Виклад основного матеріалу дослідження. За роки незалежності України соціальна робота пройшла кілька етапів становлення та розвитку. Як підкреслюють I. Звєрєва та Г. Лактіонова, за цей час створено державну систему центрів соціальних служб для молоді, виникли різноманітні служби, ініціаторами яких стали як державні структури, так і громадські організації. Зараз підготовку соціальних педагогів, соціальних працівників, підвищення професійної кваліфікації фахівців здійснюють понад десятки навчальних закладів. Постійно зростає кількість наукових досліджень 3 цієї проблематики, виходять друком видання, в яких представлений як зарубіжний, так і національний досвід, теоретичні й практичні напрацювання. Регулярним стало обговорення різноманітних питань соціальної роботи на міжнародних, національних, регіональних конференціях, семінарах, «круглих столах». Вагомим складником процесу становлення і розвитку соціальної роботи в Україні продовжують залишатися проєкти й програми соціального спрямування, що здійснюються за допомогою міжнародних організацій $[8$, с. 3].

Значний внесок у розбудову вітчизняної практики соціальної роботи зробили професійні об'єднання. Відразу за створенням у 1992 році Української асоціації соціальних педагогів і спеціалістів із соціальної роботи виникли Ліга соціальних працівників, ціла низка регіональних громадських організацій, що об'єднали фахівців соціальної роботи. Науковці І. Звєрєва та О. Безпалько відмічають, що прийняття «Етичного кодексу спеціаліста із соціальної роботи України» сприяло переходу фахівців соціальної сфери на новий рівень, який відповідає міжнародним стандартам та вимогам щодо цієї галузі професійної діяльності. Зміни, які супроводжують процес становлення соціальної роботи на кожному етапі ії розвитку, зумовлюють розробку й обгрунтування науково-теоретичних і методичних засад, що зазвичай викладені в навчальних і методичних посібниках. Поява основних навчальних та методичних посібників $є$ результатом тривалої копіткої роботи групи науковців, викладачів вищих навчальних закладів, практиків із соціальної роботи, які були учасниками партнерського проєкту «Соціальна освіта в Україні». Проєкт здійснювався, почина- ючи з 1999 року, Християнським дитячим фондом і Українською асоціацією соціальних педагогів та спеціалістів із соціальної роботи в партнерстві 3 Міжнародною федерацією соціальних працівників за підтримки Дирекції з питань розвитку та співробітництва Швейцарії. За загальною оцінкою фахівців, проєкт створив умови для постійного продуктивного діалогу як теоретиків, так $\mathrm{i}$ практиків соціальної сфери, у тому числі студентів і волонтерів, а також сприяв інтенсивному розвитку соціальної роботи і соціальної педагогіки в Україні [8, с. 4].

Необхідно зазначити, що такі проєкти значною мірою сприяли створенню умов для підготовки висококваліфікованих фахівців та подальшого розвитку соціально-педагогічної роботи в Україні. Значна кількість проєктів керується багатьма міжнародними організаціями. Нагадаємо, що міжнародна організація є формою співробітництва держав у політичній, економічній, культурній, науково-технічній та правовій сферах суспільної діяльності. Ці організації виступають основними суб'єктами забезпечення взаємодії між державами.

У вирішенні нагальних проблем соціальної роботи серед міжнародних організацій вагомою $\epsilon$ International Council on Social Welfare (ICSW) - Міжнародна рада соціального забезпечення (МРC3), яка була створена 1928 р. 3 метою сприяння обміну інформацією та досвідом роботи у галузі соціального забезпечення. Вона об'єднує на правах членів 85 національних комітетів і понад 25 міжнародних організацій. Структурні підрозділи Міжнародної ради соціального забезпечення займаються збором і поширенням інформації, проведенням досліджень соціальних проблем та їх аналізом, підготовкою, проведенням семінарів і конференцій, вживають заходів щодо зміцнення неурядових організацій [6, с. 2; 9, с. 5]. У сучасному глобальному суспільстві неурядові організації допомагають виражати та просувати потреби та прагнення людей до повноцінної участі в суспільстві та рівного доступу до ресурсів суспільства. Неурядові організації - це важливий елемент громадянського суспільства, необхідний для повної реалізації політичної демократії. Співпраця, як і конфлікти, між цими двома компонентами суспільства (урядами та неурядовими організаціями) $є$ найважливішими для захисту та просування прав людини.

3 діяльністю Міжнародної ради соціального забезпечення тісно пов'язані міжнародні організації з проблем соціальної роботи й соціальної освіти: Міжнародна асоціація шкіл соціальної роботи (МАШСР), Міжнародна федерація соціальних працівників (МФСП), Міжнародна асоціація соціальних вихователів, Свропейська асоціа- 
ція шкіл соціальної роботи, Свропейська асоціація центрів підготовки у галузі соціально-виховної роботи та інші [6, с. 3].

Міжнародна рада з соціального забезпечення це членська організація, яка має багаторічний досвід у захисті соціальної справедливості та соціального розвитку у всьому світі. Її мета - допомогти своїм членам ефективно взаємодіяти, вивести основоположні принципи 3 ïx різноманітних зусиль та енергійно впровадити ці принципи до уваги урядів, міжурядових організацій та широкої громадськості за допомогою освіти та політичних дій. Метою МРСЗ у найближче десятиліття є систематичний перехід від бачення до політики, від політики до програм та від програм до дій.

Міжнародна рада соціального забезпечення дотримується політичного, філософського та релігійного нейтралітету навіть коли стикається 3 нестандартними ситуаціями, що виникають внаслідок складних політичних подій. МРСЗ завжди різко засуджувала дискримінаційні заходи, такі як расизм. Не караючи громадян відповідних країн, вона завжди відмовлялася працювати 3 урядами, що практикують апартеїд [4, с. 63].

У 1983 р. МРСЗ встановив три пріоритети: проведення конференцій, підтримка комітетів та налагодження міцніших відносин з ООН. Пізніше, у 1986 р., у Токіо Комітет представників прийняв програму, орієнтовану на чотири основні проблеми: (1) доступ до засобів, необхідних для економічної незалежності, за участю громадянського суспільства, (2) зміцнення соціальної інфраструктури, (3) питання насильства та соціального розвитку і (4) питання технологічних змін та соціальний розвиток. Далі були зроблені пропозиції щодо подальшого випуску, розглядалися питання, які слід додати, наприклад, старіння, СНІД та інші. У тому ж році регіони також обрали програму, орієнтовану на проблеми з питань бідності (Свропа), дитячої праці та безпритульних дітей (Латинська Америка), наслідки технологічних змін (Азія), права жінок (Африка) та проблеми бездомних (Північна Америка). А після того як Берлінська стіна зруйнувалась, проблемою в Свропі постала міграція. Ще однією новою ідеєю, яку цитували в Гонконзі в 1980 році, була пропозиція, щоб МРС3 не існувала винятково як засіб забезпечення підтримки та контактів для соціальних працівників 3 різних країн. МРСЗ призначена підтримати процес і стратегію «соціального розвитку» професійної галузі, а також громади та держави. Був зроблений поступовий перехід від ідеї «соціальної роботи» до «соціального забезпечення», а потім «соціального розвитку». Цей курс був схвалений у 1989 році на засіданні Виконавчого комітету у Нідерландах. На практиці все більше контактів та обговорень було проведено 3 професіоналами, а також була створена програма обміну для соціальних працівників у багатьох країнах [4, с. 121].

Значний вплив на навчання та підготовку фахівців з соціальної роботи в усьому світі здійснює International Association of Schools of Social Work (IASSW) - Міжнародна асоціація шкіл соціальної роботи (МАШСР). На офіційному сайті цієї організації зазначено, що ця Асоціація об'єднує навчальні заклади (інститути, факультети, відділення, школи) і асоціації навчальних закладів, що здійснюють освіту у сфері соціальної роботи. Членами МАШСР є більше 500 соціальних навчальних закладів і асоціацій соціальних шкіл iз 70 країн світу. Асоціація сприяє розвитку освіти в сфері соціальної роботи в усьому світі, розробляє стандарти для підвищення якості освіти в цій галузі, підтримує інтеграційні процеси, інтернаціональний обмін, здійснює спільні дослідження 3 питань соціальної роботи в освіті. Ця міжнародна асоціація реалізує свої завдання шляхом проведення конференцій викладачів соціальної роботи (раз на два роки) та конгресів; публікацію інформаційних листків новин, участь у здійсненні програм $\mathrm{OOH}$, здійснення фінансування певних національних проєктів з питань освіти соціальних працівників, спільне фінансування 3 Міжнародною федерацією соціальних працівників та Міжнародною радою соціального добробуту видання журналу «Міжнародна соціальна робота» [3].

Спільно з Міжнародною Федерацією соціальних працівників МАШСР розробили матеріали про визначення соціальної роботи, освітні стандарти, питання етики в соціальній роботі. Основні тенденції і здобутки у сфері соціальної освіти відображені у виданні «Керівництво 3 соціальної освіти на міжнародному рівні». Воно містить інформацію про навчальні заклади 3 понад 60 країн світу, що представляють національні і регіональні асоціації і Міжнародну асоціацію шкіл соціальної роботи. Це видання подає інформацію про відмінності в національних системах навчання соціальних працівників, зміст і форми соціальної роботи в різних країнах. Міжнародна асоціація шкіл соціальної роботи має статус консультанта в Організації Об'єднаних Націй та бере участь як неурядова організація у діяльності $\mathrm{OOH}$ у Женеві, Відні, Нью-Йорку [3].

Однією із неурядових організацій, котра впливає на розвиток соціально-педагогічної роботи в Україні, $є$ асоціація, яка розташована у Європі. Європейська асоціація шкіл соціальної роботи об'єднує більше 300 різних навчальних закладів (шкіл, університетів, інших вищих навчальних закладів), що здійснюють підготовку фахівців соціальної роботи, сприяє розвитку соціально-педагогічної роботи по всій Європі, розробляє стандарти для підвищення якості соціальної роботи та 
здійснення освіти їі фахівців, заохочує міжнародний обмін, забезпечує форуми для обміну дослідженнями в галузі освітньої діяльності. Ця асоціація один раз на два роки проводить конференцію соціальних педагогів. Вона представляє освіту в галузі соціальної роботи в Свропейському Союзі, Європейській комісії Ради Європи [2].

Об'єднання зусиль соціальних працівників 3 усього світу сприяло появі міжнародної федераціï. Міжнародна федерація соціальних працівників (МФСП) є організацією, що прагне захищати соціальну справедливість, права людини і соціальний розвиток шляхом заохочення соціальної роботи, реалізації моделей передової практики і сприяння міжнародній співпраці. Ця міжнародна федерація здійснює підтримку фахівців соціальної сфери в питаннях створення необхідних умов праці, норм етики, участі у формуванні соціальної політики, освіти майбутніх соціальних працівників. Важливим завданням МФСП $є$ удосконалення соціальної роботи як професії, підтримка національних асоціацій у питаннях соціального планування, розширення контактів, обміну досвідом соціальних працівників різних країн.

Основними документами цієї організації є Статут, Міжнародний кодекс етики соціального пра- цівника, Міжнародна декларація етичних принципів у соціальній роботі. Міжнародна федерація соціальних працівників має спеціальний консультативний статус при Економічній і Соціальній Раді $\mathrm{OOH}$ і Дитячому Фонді ООН. Вона також працює з Всесвітньою організацією здоров'я (ВО3) та іншими організаціями. Вона підтримує своєю діяльністю 116 країн - членів об'єднання [5].

Висновки. Співпраця з міжнародними асоціаціями протягом останніх десятиріч сприяла розвитку соціальної роботи та соціальної педагогіки в Україні. Саме тому на сучасному етапі соціально-педагогічна робота відповідає міжнародним стандартам та вимогам щодо цієї галузі професійної діяльності. Неурядові організації розвинених країн сприяють поширенню інформації проведенням досліджень соціальних проблем та їх аналізом, а також займаються проведенням семінарів i конференцій для обміну досвідом. Міжнародні асоціації посприяли виникненню Української асоціації соціальних педагогів та спеціалістів із соціальної роботи, а їхня сумісна діяльність дозволила створити умови для навчання і підготовки висококваліфікованих фахівців соціальної сфери та подальшого розвитку соціально-педагогічної роботи в Україні.

\section{Література}

1. Міщик Л.І. Вступ до спеціальності «Соціальна педагогіка» : навчальний посібник / за заг. ред. Л.І. Міщик, О.П. Демченко. Київ : Видавничий дім «Слово», 2013. 328 с.

2. Офіційний сайт Європейської асоціації шкіл соціальної роботи: European Association of Schools of Social Work. URL: www.eassw.org (дата звернення 25.08.2020).

3. Офіційний сайт Міжнародної асоціації шкіл соціальної роботи: International Association of Schools of Social Work. URL: www.iassw-aiets.org (дата звернення 25.08.2020).

4. Офіційний сайт Міжнародної ради соціального забезпечення: International Council on Social Welfare. URL: www.icsw.org (дата звернення 26.08.2020).

5. Офіційний сайт Міжнародної федерації соціальних працівників: International Federation of Social Workers. URL: www.ifsw.org (дата звернення 26.08.2020).

6. Поліщук В.А. Інтеграція як провідна тенденція міжнародного розвитку соціальної роботи i соціальної освіти у XXI сторіччі. Психолого-педагогічні науки. № 4. Ніжин, 2012. С. 1-6. URL: irbis-nbuv.gov.ua/cgi-bin/irbis.../cgiirbis 64.exe?... (дата звернення 23.08.2020).

7. Ребуха Л. Історичні аспекти становлення професії соціального працівника. Вісник Національної академії Державної прикордонної служби України. Педагогіка. № 3. Тернопіль, 2017. С. 1-9. URL: nbuv.gov.ua/j-pdf/Vnadped_2017_3_15.pdf (дата звернення 23.08.2020).

8. Соціальна робота в Україні : навч. посіб. / уклад. І.Д. Зверева, О.В. Безпалько, С.Я. Харченко та ін. За заг. ред.: І.Д. Звєрєвої, Г.М. Лактіонової. Київ : Центр навчальної літератури, 2004. 256 с.

9. International Council on Social Welfare: 80 years of history (1928-2008). Presses de l'EHESP, 2008. $158 \mathrm{p}$.

\section{References}

1. Mishchik L.I. (2013) Vstup do spetsialnosti "Sotsialna pedagogika": navchalniy posibnik [Introduction to the specialty "Social Pedagogy": a textbook]. For the general edit. : L.I. Mishchik, O.P. Demchenko. Kyiv : Publishing House "Slovo". 328 p.

2. Official site of European Association of Schools of Social Work. URL: www.eassw.org (the date of the request 25.08.2020).

3. Official site of International Association of Schools of Social Work. URL: www.iassw-aiets.org (the date of the request 25.08.2020). 
4. Official site of International Council on Social Welfare. URL: www.icsw.org (the date of the request 26.08.2020).

5. Official site of International Federation of Social Workers. URL: www.ifsw.org (the date of the request 26.08.2020).

6. Polishchuk V.A. (2012) Integratsiya iak providna tendentsiya mizhnarodnogo rozvitku sotsialnoi roboti i sotsialnoi osviti u XXI cstorichchi [Integration as a dominant trend in the international development of social work and social education in the XXI century]. Psychological and Pedagogical Sciences. № 4, Nizhyn. P. 1-6.

7. Rebukha L. (2017) Istorichni aspekti stanovlennya professii sotsialnogo pratsivnika [Historical aspects of the formation of the profession of social worker]. Bulletin of the National Academy of the State Border Guard Service of Ukraine. Pedagogy. № 3, Ternopil. P. 1-9.

8. Sotsialna robota v Ukraini [Social work in Ukraine: textbook] / draft. I.D. Zvereva, O.V. Bespalko, S. Y. Kharchenko and others. For the general edit.: I.D. Zvereva, G.M. Laktionova. Kyiv : Center for Educational Literature, 2004. $256 \mathrm{p}$.

9. International Council on Social Welfare: 80 years of history (1928-2008). Presses de l'EHESP, 2008. 158 p. 